\title{
Examining the Necessity of Reflective Module: Literacy Numeracy Skill of Students Elementary School
}

\author{
Yeni Rakhmawati ${ }^{1}$, Ali Mustadi 2 \\ DOI: $10.35445 /$ alishlah.v13i1. 534
}

\begin{tabular}{l} 
Article Info \\
\hline Keywords: \\
Reflective Module \\
Literacy \\
Literacy Numeracy \\
Primary School
\end{tabular}

Kata kunci:

Reflective Modul

Literasi

Literasi Numerasi

Sekolah Dasar

\begin{abstract}
The research aims to describe the need for reflective modules in building literacy skills of primary school students. The research used a quantitative descriptive method. The population was the fifth-grade primary school students that implement the 2013 curriculum with A accreditation-the data collection technique used non-test with observation instruments, questionnaires, interview guidelines, and literature review. The sample was taken using a purposive random sampling technique. The sample in this study was 126 students. The results showed that students and teachers need a reflective module to build numeracy literacy. The reflective module has the potential to build numeracy literacy skills. Literacy skill is closely related to reflective thinking processes, in which reflective thinking is a critical thinking process for making an assessment. Self-assessment aims to measure the extent of an individual's abilities to encourage the individual to develop self-potential.
\end{abstract}

\begin{abstract}
Abstrak
Tujuan penelitian mendeskripsikan perlunya modul reflektif dalam membangun keterampilan literasi siswa sekolah dasar. Metode penelitian yang digunakan adalah metode kuantitatif deskriptif. Populasinya adalah siswa kelas V SD yang menerapkan kurikulum 2013 dengan akreditasi A. Teknik pengumpulan data menggunakan non tes dengan instrumen observasi, angket, pedoman wawancara, dan studi pustaka. Sampel diambil dengan menggunakan teknik purposive random sampling. Sampel dalam penelitian ini sebanyak 126 siswa. Hasil penelitian menunjukkan bahwa siswa dan guru membutuhkan modul reflektif untuk membangun literasi numerasi. Modul reflektif berpotensi membangun keterampilan literasi berhitung. Keterampilan literasi sangat erat kaitannya dengan proses berpikir reflektif, dimana berpikir reflektif merupakan proses berpikir kritis untuk membuat penilaian. Penilaian diri bertujuan untuk mengukur sejauh mana kemampuan individu dalam mendorong individu untuk mengembangkan potensinya.
\end{abstract}

\footnotetext{
${ }^{1}$ Universitas Negeri Yogyakarta, Yogyakarta, Indonesia Email: yenirakhmawati247@gmail.com

${ }^{2}$ Universitas Negeri Yogyakarta, Yogyakarta, Indonesia Email: ali_mustadi@uny.ac.id
} 


\section{INTRODUCTION}

Benchmark measuring students' learning success is determined through national examination that measures students' success in cognition. It is not in line with the objectives of the 2013 curriculum, which refers to mastery in the cognitive, affective, and psychomotor domains. Nevertheless, educational outcomes in the cognitive domain are still in the low category. Indonesia proves this as 72 of 72 countries in reading and mathematics in the PISA (International Student Assessment Program) ranking (OECD, 2018). Based on these results, Indonesia is still in the stage to think memorization, reasoning students still low.

Literacy skill is the basic ability of someone to gain and process information. Literacy skill in Indonesia is in the very low category. The mathematics literacy of students are in the poor category is $77.1 \%$, the sufficient category is $20.6 \%$, and the good category is $2.3 \%$ (INAP SD, 2016). This assessment is based on high-order thinking skills that are formed due to a meaningful learning process. The government has begun to build up several innovations in education to improve the quality and quality of students. One of them is the literary movement School or Gerakan Literasi Sekolah (GLS) initiation in 2015. The movement is intended to enhance interest in reading and writing literacy activities for 15 minutes before learning.

Literacy activities are not only reading and writing activities. The government in Indonesia has begun to develop the National Literacy Movement, which started in 2017, which includes literacy, numeracy, scientific literacy, digital literacy, financial literacy, and cultural literacy (Kemendikbud, 2017). School literacy activities consist of three stages. The habituation stage consists of reading books in the school environment. The development stage consists of integrated reading activities, reading together, discussion, and development activities. The implementation of school literacy is still at the habituation stage. Training is still limited to building a literacy environment by reading to have not developed competencies for literacy skills.

The urgency of this research is to address literacy problems that exist in Indonesia. Indonesia is entering a literacy crisis, but research on literacy in primary schools is still minimal. There has not been much research on literacy problems and solutions to these problems. In this study, the variable to be studied was the students' numeracy literacy skills. Numerical literacy is categorized as a branch of mathematical literacy (PISA, 2012). Numerical literacy is the ability to reason, formulate, use, and interpret calculations in various contexts of daily life problems efficiently (Abidin, Mulyati, and Yunansah, 2017).

Numerical literacy indicators include interpreting data, counting operations, and measurements something (Kemendikbud, 2017). The implementation of numeration contains the skills to apply mathematical concepts and rules in daily situations. Mathematics needs implementation, not only memorization. Memorizing symbols can produce correct results, but learning becomes non-existent (İncikabıa, Ayanoğlub, and Uysal, 2020). In the context of fifthgrade primary school students, numeracy literacy is synthesized as the ability to interpret symbols, read data, and solve problems through story problems. Daily issues are represented as mathematical problems to be solved later (Craig and Guzman, 2018). Literacy and numeracy is an essential requirement for students. Literacy and numeracy skills are advantageous for student life to lead students to a good life (Hartley and Horne, 2006).

This study attempts to describe the need between modules combined with reflective thinking. This module reflection is attempted to develop students' numeracy literacy skills. Modules can be an alternative to provide facilities for students to improve meaningful learning processes. Likewise, Sejpal (2013) suggests that modules are arranged systematically and organized to provide learning opportunities through activities that support independence, learning evaluation, and equipped with activity instructions. The module as a teaching and learning activity program that students can use independently is called a learning module (Prastowo, 2015; Winkel, 2009; Russel in Reed, 2001). This module is about the activity of reflective thinking. Reflective thinking (reflective thinking) is an 
active process of thinking and critical that aims to find a conclusion (Hong and Choi, 2011; Ashwin, Boud, and Coate, et al., 2015). The reflective thinking process is a higher-order thinking skill (Suharna, 2013; Edwards, 2017). Reflective thinking is used to facilitate self-development and effective learning facilities (Paterson and Chapman, 2013).

The reflective module contains reflective activities that trigger students to think critically. When students can think critically, students will be more able and easier to develop their literacy skills. The story that is developed containing reflective stories so that through the characters and story content presented, students can assess themselves. As Beers, Beers, and Smith (2010) found, students, can judge the good and bad character in the story through the story's development. The story development is based on the conditions in the environment (Nurgiyantoro,2013).

Furthermore, it revealed that reflection is a deep thought process that involves asking and answering activities (Smith, 2013; Pacheco, 2005). Reflection includes a simple overview and description of a learner's activity and requires cognitive and metacognitive activities in which the learner recognizes what has been learned (Oo and Habok, 2020). In learning activities, reflective activities are carried out at the end of the activity to provide reviews and conclusions. This is a compelling reason why books or media in elementary schools should create content about reflective thinking.

The importance of literacy and reflective thinking is applied to fifth-grade students, namely to equip students to easily solve complex problems. Besides that, students need a lot of insight to judge good and bad about something. Students' characteristics of fifth-grade primary school are that they progress to solve daily problems and have confidence that they can do useful things for others and their environment (Rakhmawati and Mustadi, 2019). The development stage of student thinking is already at the construction stage of concrete (Schunk, 2012). Besides, the students had got in the stage to judge themselves, to make a decision correct or wrong of an action. Students have been able to provide a self-reflection independently.

Students still have to build habits to apply literacy in everyday life. Numerical literacy is defined as the ability to solve problems in daily life (Stecey \& Tuner, 2015). Research on numeracy literacy in elementary schools is still minimal. The research by Musliman et al. (2013) who said that numeracy literacy is very useful to solve problems in the social world. In addition, research from ( Tariah, 2014; Ojose, 2011) explains that literacy and numeracy are needed to equip students for a better life. Starting from this research, literacy skills are needed for students. Especially if you start developing it from an early age, the results will be more significant. Literacy skills are related to social life, namely that individual literacy and numeracy abilities can be useful in social life.

This research provides an overview of the condition and level of students' literacy. By looking at the facts that occur in the field, various solutions and breakthroughs can solve this problem. One of them is an innovative module containing reflective thinking content that can help students improve literacy skills. Modules that contain a lot of activities about reflective thinking. The reflective module contains morning literacy activities, which contain reflective story activities, reflective journals, self-stories, practice questions, motivational figures, and which train students' numeracy skills. Each activity is given a self-assessment sheet (reflection) to assess self-competence. This module equips students to reveal unique things in daily life related to numeracy literacy. The capacity of literacy numeracy is the ability to read and make sense of information in a graph or table and solve the problem. The scope of numeracy literacy in the world of fifth-grade primary school students is to understand story questions and coherently convey solutions and interpret data.

\section{METHODS}

The research used a descriptive quantitative method. This study uses a quantitative descriptive method because the research analyzes and describes data in numbers to explain a phenomenon and meanings or conclusions drawn (Ananda \& Fadhli, 2018). This research was used to define the module's reflective needs to build students' numeracy literacy skills. The research was carried out 
from March to May 2019. The study was carried out in public primary schools that implemented the 2013 curriculum with A accreditation in Mlati sub-district, Sleman Regency, for the 2018/2019 academic year.

Study participants were selected through a random sample. So that the research results can be generalized. This research was attended by 126 students and 14 fifth grade teachers public primary school that implements the 2013 curriculum with A accreditation in Mlati sub-district, Sleman Regency, for the 2018/2019 academic year. The research instruments used included observation, questionnaires, interview sheets, and literature review. The questionnaire and interview instruments were used to collect descriptive quantitative research data. The data analysis used was descriptive statistics. Descriptive statistics are data analysis to reveal and interpret data sets. The data can be conveyed and readable to the general public. Descriptive analysis is the statistic used to analyze data by describing or describing the collected data without making generalized conclusions or generalizations (Sugiyono, 2017).

\section{FINDINGS AND DISCUSSION}

\section{Interview Results}

Interviews were conducted with the fifth-grade teachers at SDN Sendangadi 1 and SDN Sinduadi 1. The results obtained were information about implementing the School Literacy Movement (GLS) program, student literacy skills, and character values. The teacher revealed that the School Literacy Movement (GLS) stated that this program was essential for students as a provision for students to instill reading interest further and develop students' reading understanding. However, the implementation of the program has not been carried out well. Students tended to play rather than read during literacy activities. The following are the results of interviews with teachers of SDN Sendangadi 1 and SDN Sinduadi 1.

"The implementation of literacy in our school is limited to fulfilling the program's obligation to read, so children are given 20 minutes to read-sources of reading according to the passions of students in the library. The teacher is only controlling. Our school has implemented literacy activities quite well, it's just that there are still some children who prefer to play or chat with friends instead of reading." (SDN Sendangadi 1 teacher)

The results of the following interview discussed the correlation between the School Literacy Movement (GLS) and literacy skills. Based on the results of the interview, it is identified that numeracy literacy skills are still lacking. Besides, students' literacy skills are still low, particularly in numeracy literacy.

"The good thing is when it comes to literacy time, the children have read the story with the subject matter so that when the lesson is done, someone will come in. But, it is an only child, it's difficult to even read, particularly when I ask to read the material. "When it comes to students' abilities, which are still lacking during maths, Ma'am" "Their numeracy problem has no problem, at least they are not accurate enough, but if there is a story problem, they will be confused about the solution." (SDN Sinduadi 1 teacher).

The data from the field are in accordance with several research results that suggest that Indonesia's implementation is still lacking. As everywhere, Kusrieni (2014: 110) argues that mathematics is still a subject that students avoid. One of the most significant difficulties is mathematics in everyday life, which is simply applied to elementary school children in story problems. Students have difficulty understanding the meaning and purpose of the problem. In this case, the difficulty of students lies in numeracy literacy skills. Numerical lite is defined as the ability to solve problems in everyday life. The challenges faced by students in academic skills are directly 
related to the belief that they cannot learn or cannot follow learning (Sadewi, 2012). Thus, many students have difficulties in school not because they cannot do it successfully but because they cannot do it successfully. Student confidence encourages students to try their best according to their abilities and understand their limits.

Further information is about the availability of media in books to support the school literacy movement (GLS). The books available in schools are still limited. There are several books on general knowledge and storybooks, but these books have been published for a long time. The teacher stated that books for literacy still lacked variety. Students only read the same book, so they quickly got bored.

"The books available for literacy are still limited, not too various, and usually all have been read by students. At least many books lessons, book story too sober. It is often better to bring books from home, but only one or two children bring them. Children often easily get bored if asked to read, but they like to read if they consist of pictures. They also like books with puzzles or quizzes." (SDN Sendangadi 1 teacher)

The book availability is not sufficient to provide provision for activities according to student needs. The teacher stated that the books in the school did not have a specific purpose, meaning that the reading materials available did not have the aimed achievement. Many schools still lack books to support literacy. This fact is in line with Tahmidaten and Krismanto (2020) research, which explains that the availability of facilities and infrastructure for libraries in Indonesia is still lacking, library administration management is often neglected. A very influential impact is on student literacy reading materials. The book availability in schools has not included the values and needs of students, particularly the importance of character and good behaviour. Moreover, both schools were no books related to arithmetic activities.

"The good news is books that are material has activities that attract students to read. So not only read, but also learn from these activities. The book as it was not there at the school we have. Many books do not include character lessons for students. The important thing is that they are funny that are interesting for students. Books still simple. There is a book about the activities of counting have never found except a math book. The kids don't read math books in the morning either." (SDN Sendangadi 1 teacher)

When the teacher was asked questions about the reflective module, the teacher stated that he was interested in the module. The teacher noted that the module could be used for student literacy activities and was best at meeting the knowledge needs of students. This module could attract students because it is related to students. Students prefer things that are related to them. Besides, the module contains various stories and activities so that students do not get bored easily.

Based on the excerpt from the interview results, it can be synthesized that teachers need modules to support school literacy activities. The reflective module is a module development for students' numeracy literacy needs. The required module is a module with thoughtful content so that students can make it suitable to meet the needs and character of students.

\section{Observation Results}

Literacy activities are carried out for 15-20 minutes to sing the Indonesia Raya song and read books according to the students' wishes, available in the library or reading corner. The guideline module for literacy activities from the government is not yet known, so the stages of literacy activities have not been appropriately implemented. The available books are still classified as insufficient so that some students do not read books.

The reading program for 15 minutes per day has a good impact on students. However, it will make students find it difficult to get used to reading if not accustomed to it. Ortlieb (2010), in his research, argued that every day for 15 minutes, students read magazines, reading newspapers with a 
rotation system, meaning that students read consecutively. It makes students no longer complain in terms of reading, and reading activity becomes a fun activity.
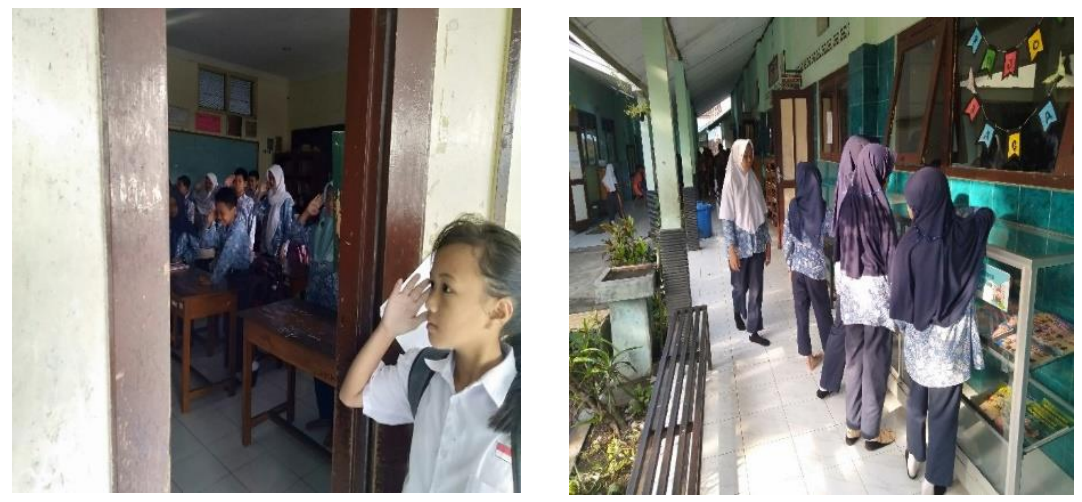

Figure 1. School Literacy Activities that Students usually do

The guideline module for literacy activities from the government was not available yet, so the stages of literacy activities had not been carried out properly. The available books were classified as insufficient so that some students did not read books. Besides, students showed a bored attitude reading books that had been read. Triatma (2016) argues that expensive books and limited library facilities cause low reading interest in schools. The books available were old published books, so the information contained in the books was still not up to date.
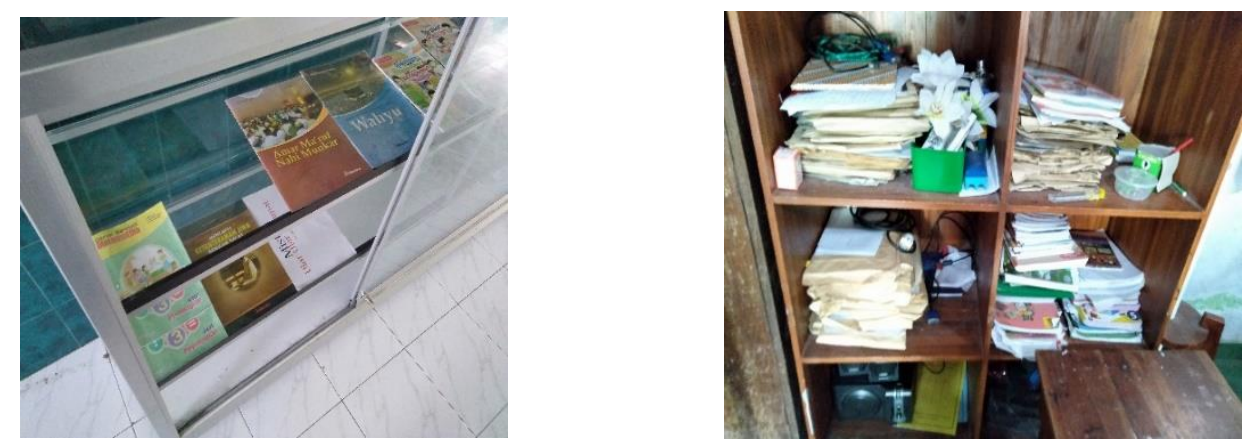

\section{Figure 2. The Condition of The Variety of Books Available in Each School}

Some of the books available included textbooks, storybooks, and novels. Textbooks were books that were rarely read. Students were more interested in reading books that had exciting pictures and colours. The characters in the book also affected the interest in reading books. It can be seen that students choose books by looking at the characters they want to read. Colours and images are supported to understand better illustrations (Gilang, Sihombing, and Sari, 2017). Observations were made during literacy activities and learning activities. The results showed that the students' numeracy literacy was still low. When literacy activities were carried out, no students read books about numeracy (numbers). The book's source was not sufficient to cause the students to not read about the book associated with the number. Students were not interested in exploring insights related to numeration (numbers).

When learning activities took place, some students gave up when working on essay questions. Besides that, students always asked the teacher to explain the meaning of the questions. Students who found it too tricky choose not to solve the problem. The difficulty in understanding the meaning of the questions indicated that students' reading comprehension was still lacking. Some students had complained when the math lesson took place, "Mom, don't study math, it's hard". Students did not understand the benefits of numeracy activities in daily life.

Even though by understanding numeracy literacy, students will have better adaptability and self-confidence. In line with that, literacy and numeracy skills are the basis for understanding 
material and useful in social life (Musliman et al., 2013). Students with good literacy and numeracy skills can easily advance to the next level to gain more knowledge. Student learning needs are not only concerned with cognitive abilities. The ability of students to analyze problems is needed, especially in the current learning conditions, which require students to study independently and use distance learning methods. Besides the limited learning conditions, students must also prepare themselves for a new learning model, namely, literacy and numeracy.

The results of further observations relate to the students' character. Some of the characters that emerged were student's confidence, concern, responsibility, and independence. At the time the teacher asked for the answer, most major students choose to keep silent. Students who were clever and had high self-confidence always answered the teacher's questions and actively conducted discussions. This condition caused students who were not active to feel left behind and low their level of self-confidence.

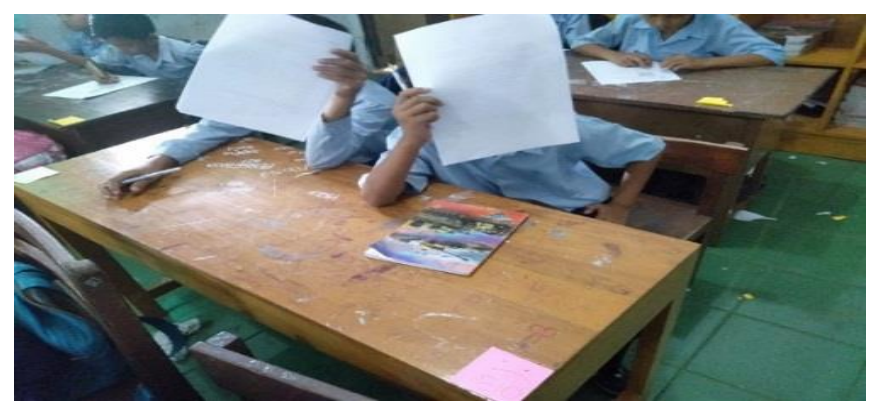

Figure 3. Some Students Showed Insecurities when Doing Schoolwork

When literacy activities were carried out, the character of students' self-confidence could be seen from the difference between students who were confident and students who were not confident. Nurgiyantoro (2013) explains that the books that are read can build students' character, so it becomes important for students to read. So that students have a character that is formed. Students who had self-confidence rushed to choose the book they wanted to read, then discuss by telling the results of what they had read. However, students who were not confident chose the same book as their previous choice of friends. Students who could not decide which book they wanted to read and decided to follow their friends' choices. Moreover, students who were not confident tended to be quiet when other friends told stories.

Literacy activities have been carried out since 2015, but implementation in the field is still not optimal. Literacy activities have not shown significant progress for students. Students still do not understand the purpose of reading, the need to read, and the importance of literacy activities for themselves. Literacy activities are used to equip students before participating in learning activities. Students could reveal their reading results during the learning process and prepare students to improve their reading comprehension skills. Kharizmi (2015) argues that it is wrong because low proficiency reading elementary students in Indonesia is as long as these students get more lessons memorization rather than practice, incl compose.

Media became the most support for improving students' interest. However, there had not been found a book containing the material which was packaged attractively for students. There were also no books that provided character strengthening for students. Most of the books contained cognitive aspects, while affective aspects were not given enough attention. The available media can be stated as having not met the literacy needs of students. Literacy activities are still limited to reading. Literacy activities should be carried out with various activities to get new experiences that are interesting to them. This situation is very contrary to the critical role of place and media literacy. In line with that, Ramandanu (2019) explains that a well-managed literacy place can increase reading interest and make school members lifelong learning. 
Based on the observations above, it can be synthesized that students need the right media to develop numeracy literacy. The media must contain literacy material related to students' daily lives so that students can reflect on it in their daily lives.

\section{Questionnaire for Teacher and Student Needs}

Questionnaires for the teacher were distributed to 14 fifth-grade teachers in Mlati District. The questionnaire consisted of 26 questions regarding the need for literacy activities, including implementation and the need for media to support students' abilities and character. Detailed questionnaire results can be seen at the following summary results of the questionnaire show that:

\section{Table 5. Teacher questionnaire results}

\begin{tabular}{|c|c|c|}
\hline No. & \% & Information \\
\hline 1. & 100 & The teacher agrees that literacy activities need to be developed \\
\hline 2. & 85.8 & Guide activities of the literacy needs of students. \\
\hline 3 . & 78.6 & $\begin{array}{l}\text { Module activities of literacy are essential to develop literacy skills } \\
\text { numeracy. }\end{array}$ \\
\hline 4. & 78.6 & The teacher agrees to the availability of the literacy module \\
\hline 5. & 92.9 & Teachers need literacy activity modules to develop student literacy. \\
\hline 6. & 92.9 & $\begin{array}{l}\text { Teachers need literacy activity modules with reflective content to } \\
\text { develop students' numeracy skills. }\end{array}$ \\
\hline 7 . & 85.8 & $\begin{array}{l}\text { Teachers need literacy modules for students to contain reflective } \\
\text { activities to measure students' abilities. }\end{array}$ \\
\hline 8. & 92.9 & $\begin{array}{l}\text { The teacher reveals that reflection activities are needed as an evaluation } \\
\text { activity. }\end{array}$ \\
\hline
\end{tabular}

Note: Filled by 14 teachers

Based on the questionnaire results above, several other points obtained from the questionnaire data are that teachers need the media to develop students' abilities and character. The teacher argues that reflective thinking is an essential basis to form basis for module development. Modules are adapted to various activities such as reading the information, telling stories, filling out quizzes, and writing journals. Based on the questionnaire results, it was found that the teacher needed modules to meet the needs of students. The module contains activities that support the development of literacy skills by using reflective thinking process content.

The teacher stated that literacy needs to be developed. The teacher conveyed that the instructions for implementing literacy activities were needed considering that there were no instructions for literacy activities in schools. This statement corresponds to a collection of books to attract and foster interest in reading students. At the same time, the reading area covers the school environment in the form of a foyer equipped with a collection of books (Pradana, 2020). Especially in numeracy literacy, it has never been implemented in the implementation of literacy. Numeracy literacy has not been developed in schools, even though it is very important to be developed.

The teacher also stated that he could not make a module guide. In comparison, literacy activity guidelines need guidance. The reflective content of the module is necessary. The teacher states that reflective thinking processes can be used to develop students' thinking patterns. Reflective thinking guides students to think deeply and through the evaluation process. So that students can judge something.

Questionnaires were distributed to 126 students fifth-grade students of SDN Tlogoadi, SDN Sinduadi 1 Sendangadi SDN 1, and SDN Nglarang in District Mlati. Primary schools were selected based on random choices and expressed willingness to fill out a questionnaire. The questionnaire consisted of 38 questions that contained students' needs for literacy activities. Students must fill in according to the real conditions and conditions. Students should not be influenced by other people 
so that the filling is done with strict care so that the results obtained are in accordance with reality. The results of the student questionnaire showed that:

Table 6. Student Questionnaire Results

\begin{tabular}{lcl}
\hline No. & $\mathbf{\%}$ & \\
\hline 1. & 48.4 & students like reading books before learning activities in class. \\
\hline 2. & 89 & students like books containing a variety of activities, material, and practice. \\
\hline 3. & 62.9 & students like storybooks. \\
\hline 4. & 85.7 & students like books that have characters and story characters. \\
\hline 5. & 92.9 & students like filling out quizzes. \\
\hline 6. & 81.7 & $\begin{array}{l}\text { students like books that contain the school environment and the } \\
\text { environment around students. }\end{array}$ \\
\hline 7. & 77,8 & students love to imitate their idols' positive behavior. \\
\hline 8. & 58.8 & students like to reflect on activities or behaviors that have been done.
\end{tabular}

Note: Filled in by 126 students

In parallel with the questionnaire results, some of the points obtained from questionnaire data are that students need the media to write. Besides, students like coloring books containing pictures with cartoon characters, and these books contain material that students can quickly mastery. Students like a comfortable place to study, do not like rude friends, and students like a school environment that can express expression. Students want to evaluate themselves or reflect on a character or event that has happened to them.

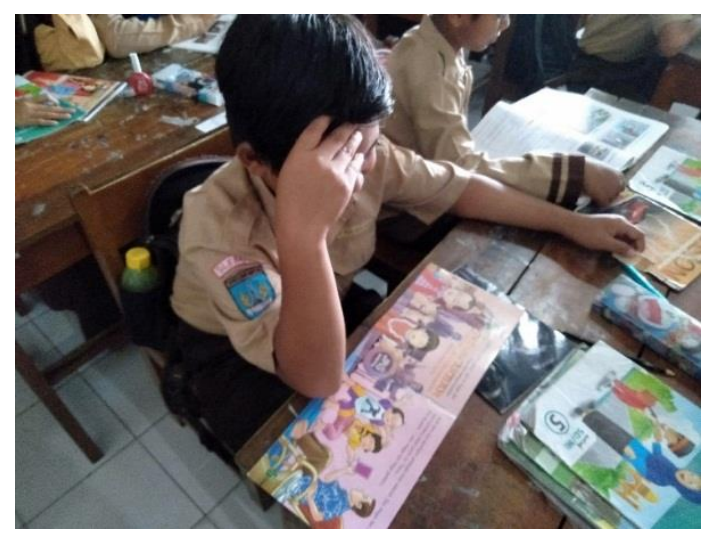

\section{Figure 4. Students Show Interest in Pictorial Stories that have Characters to Emulate}

Students show an interest in carrying out a variety of activities before undertaking core learning activities. Discussion, reading, drawing, or morning quiz is very interesting for students. Besides, students choose books or activity packages that contain various activities. Students also show an interest in picture storybooks (Nurgiyantoro, 2013). Following students who like characters or story characters, students choose books with lots of pictures and illustrations. The importance of illustrations and pictures in children's books was conveyed by Gilang, Sihombing, and Sari (2017) that books with context and adequate illustrations will influence the process and mindset of early childhood through the subconscious.

They like to imitate the characters or characters in the story. Not only that, they chose a quiz activity to warm up before core learning. Students like things related to their environment, such as stories related to their area. Students show the attitude of being able to evaluate themselves against the characters in the story.

The material story is a material development on numeracy literacy, including data material, number operations, and measurement. In addition, there are reflective stories to reflect on the character of the story with oneself. Furthermore, there are reflective questions, reflective journals, and self-stories to develop a self-evaluation process. 
Based on the questionnaire results, it was found that teachers and students need the latest and exciting innovations to meet literacy needs. Students need media that contains various activities that facilitate students' needs to read and media that is easy to understand. The media includes various activities that are joint in the form of stories and contain characters that can be role models for students. The movement of reflecting on figures becomes interesting for students.

\section{Results of Literature Review}

This research is based on (Lickona, 2013) explaining that moral reflection plays an essential role in developing cognitive aspects. Reflection activities can be used to build abilities in the cognitive domain. In the research, the domain of cognitive that addressed literacy numeracy developed through the school literacy movement.

According to Smith (2013), reflection is a deep thought process that involves asking and answering activities based on theoretical studies. Students need the reflective thinking process. The students measure how much understanding of themselves. Students can identify the needs he can develop their potential for themselves better. Reflection activities include activities to assess themselves. Students can assess what they want and what they don't want for the scope of primary school. Through self-evaluation, students can understand their needs of himself and can overcome the shortage itself (Rakhmawati \& Mustadi, 2019).

Students' needs for reflective thinking activities can be packaged through modules. The advantage of a module that it is used to achieve the purpose of developing a module. Modules can be used to teach in the cognitive, affective, and psychomotor domains. As, Matanluk, Mohammad, Kiflee, \& Imbug (2013) explain that modules can improve cognitive abilities in critical thinking levels. The module contains various activities that facilitate students to develop their mindset.

The reflective module is a module containing the reflection that can guide students to develop literacy skills independently. Student reading books currently do not contain evaluation activities that assist students to get to identify themselves better. The books available are still limited and do not include some activities for students.

Introduction and habituation of numeracy can be done in literacy activities in the morning. Numeracy literacy aims to take advantage of arithmetic as a way of solving problems. The relationship here is morning literacy which contains a numerical component about daily activities to foster numeracy literacy skills. Students are accustomed to recognizing numeracy and making numeration a fun activity.

The superiority of the reflective module is that students carry out reading activities and various reflective activities to assess their abilities. Through reflective stories, students not only read stories, but students can reflect and choose suitable characters to be imitated or abandoned. Reflective activities in the module are activities to recall the experiences that students have had so that the processes that students carry out are more meaningful to improve students' numeracy literacy skills (Purpura, Hume, Sims, \& Lonigan, 2011). The advantages that others include: (1) independent student (2) attract the attention of students because of the varied activities, (3) train students to express opinions.

Aspects of reflective modules for fifth-grade students cover the module's suitability with the student's character, content related to the literacy numeracy module. The module contains activities reflective thinking. The module is used as independence, the module as self-evaluation activities. The module is developed based on reflective activities. Reflective activities in the module include packaged material through reflective stories, let's reflect, let's practice, motivational figures, information on the "Did you know?" Sheet, reflective journals, and self stories. 
Reflective thinking processes train students to provide an assessment of themselves about the extent of their abilities. By identifying students themselves, students can develop their strengths and overcome their weaknesses. Through a reflective thinking process packaged through learning media modules, students can give self-assessments, and students develop numeracy literacy skills. The module content, which contains various reflective activities combined with numeracy literacy material, attracts students' attention to numeracy literacy materials. Thus, based on this research, it can be concluded that students and teachers are interested and need media in reflective modules to develop students' numeracy skills. Moreover, based on data and literature review, the reflective module has the potential to develop numeracy literacy skills because the reflective thinking process rests on higher-order thinking processes that make it easier for students to understand numeracy literacy material.

The time limitation in the research causes this research not to be able to reach many areas. This research aims to develop education, especially in literacy, given the different urgency of literacy conditions in Indonesia to get immediate attention from various research perspectives. It is hoped that future research can reach many areas so that more diverse data can be obtained. In addition, this research can be used to reference future researchers with literacy variables of other kinds. It is also hoped that with the description of this research, many innovative solutions from future researchers will emerge.

\section{REFERENCES}

Abidin, Y., Mulyati, T., \& Yunansah, H. (2017). Pembelajaran literasi: strategi untuk meningkatkan kemampuan literasi matematika, sains, membaca and menulis. Jakarta: Bumi Aksara

Ananda, Rusydi \& Fadhli Muhammad. (2018). Statistik pendidikan (Teori dan praktik dalam pendidikan. Medan: Widya Puspita

Ashwin, P., Boud, D., Coate, K., Hallett, F., Keane, E., Krause, K-L., Leibowitz, B., MacLaren, I., McArthur, J., McCune, V., \& Tooher, M. (2015). Reflective teaching in higher education. London: Paul Ashwin and Bloomsbury.

Beers, C. S., Beers, J. W, \& Smith. J. O. (2010). Literacy Instruction. New York London: THE GUI LFORD PRESS

Craig, Jeffrey, and Lynette Guzmán. (2018). Six propositions of a social theory of numeracy: interpreting an influential theory of literacy. Numeracy 11, Iss. 2 (2018): Article 2.https://doi.org/10.5038/1936-4660.11.2.2

Hartley, Robyn \& Horne, Jackie. (2006). Researching literacy and numeracy costs and benefits: what is possible. Literacy \& Numeracy Studies, 15 (1), 2006

Hong, Yi-Chun \& Choi, Ikseon. (2011). Three dimensions of reflective thinking in solving design problems: a conceptual model. Education Tech Research Dev. Vol 59: 687-710. DOI 10.1007/s11423-011-9202-9

İncikabıa, Lütfi , Ayanoğlub, Perihan , Uysal, Ramazan. (2020). Sixth-Grade Students' Procedural and Conceptual Understandings of Division Operation in a Real-Life Context. International Electronic Journal of Elementary Education September 2020, Volume 13, Issue 1, 127-138. https://doi.org/10.26822/iejee.2020.171

Indonesia National Assessment Programme. (2020, September 15). Retrieved From Pusmenjar Kemendikbud Indonesia. Protection Agency website: https://pusmenjar.kemdikbud.go.id/inap-sd/

Kemendikbud. (2017). Materi pendukung literasi numerasi. Jakarta: Tim GLN Kemendikbud

Kemendikbud. (2017). Peta jalan gerakan literasi nasional. Jakarta: Tim GLN Kemendikbud

Kementrian Pendidikan and Kebudayaan. (2016). Indonesian National Assesment Programme. Jakarta: Pusat Penilaian Pendidikan

Lickona, T. (2013). Pendidikan karakter : Panduan lengkap mendidik siswa menjadi pintar and baik. (Terjemahan Lita S) Bandung: Penerbit Nusa Media . (Buku asli diterbitkan tahun 2008)

Matanluk, O., Mohammad, B., Norizah, D., Kiflee, A., \& Imbug, M. (2013). The Effectiveness of Using Teaching Module Based on Radical Constructivism toward Students Learning Process. Procedia - Social and Behavioral Sciences, 9o(InCULT2012), 607-615. https://doi.org/10.1016/j.sbspro.2013.07.132 
Musliman, R., Rahayah, S., \& Din, R. (2013). Assessing students' spatial intelligence for literacy and numeracy skills. Procedia - Social and Behavioral Sciences ,695-701. https://doi.org/10.1016/j.sbspro.2013.07.142

Nurgiyantoro, Burhan. (2013). Sastra anak: Pengantar pemahaman dunia anak. Yogyakarta: Gajah Mada University Press

OECD. (2018). "Programme for international student assessment (PISA) Result from PISA 2018" www.oecd.org.edu/pisa

Ojose, B. (2011). Mathematics literacy: are we able to put the mathematics we learn into everyday use ? Journal of Mathematics Education. Vol 4, No. 1, p 89-100, 2011

Ooa, Tun Zaw, Habók, Anita. (2020). The Development of a Reflective Teaching Model for Reading Comprehension in English Language Teaching. International Electronic Journal of Elementary Education September 2020, Volume 13, Issue 1, 127-138. https://doi.org/10.26822/iejee.2020.171

Pacheco, Q. A. (2005). Reflective teaching and its impact on foreign language teaching. Actualidades Investigativas en Educación, 5(3), 1-19. https://doi.org/10.15517/aie.v5i3.9166

Paterson, C., \& Chapman, J. A. (2013). Enhancing skills of critical reflection to evidence learning in professional practice. Physical Therapy in Sport: Official Journal of the Association of Chartered Physiotherapists in Sports Medicine, 14(3), 133- 138. https://doi.org/10.1016/j.ptsp.2013.03.004

PISA. (2012). Assesment and analytical framework: mathematics, raeding, science, problem solving and financial literacy. Paris: OECD Publisher, 2013, p 65-76.

Prastowo. (2015). Panduan kreatif membuat bahan ajar inovatif. Yogyakarta: Graha Ilmu, 2012.

Kusrieni, Devi. (2014). Confidence relationship with cheating behavior. Psychopedia Journal: 2014. vol.3, no.2, p. 100-111

Sadewi, AI, Sugiharto, DYP., \& Nusantoro, E. (2012). Increase confidence in mathematics lessons through symbolic modeling techniques content assignment services. Jurnal Indonesian Journal of Guidance and Counseling: Theory and Application, vol 1, no. 2, p. 8-12

Tahmidaten, Lilik \& Krismanto, Wawan. (2020). Permasalahan Budaya Membaca di Indonesia (Studi Pustaka Tentang Problematika \& Solusinya). Scholaria: Jurnal Pendidikan dan Kebudayaan, Vol. 10 No. 1, Januari 2020: 22-33

Ortlieb, Evan. T. (2010) Beyond Just Books: Sparking Children's Interest in Reading. International Journal of Education, 2010, Vol. 2, No. 2: E9

Triatma, Nur Ilham. (2016). Minat baca pada kelas VI Sekolah Dasar Negeri Delegan 2 Prambanan Sleman Yogyakarta. E-Jurnal Prodi Teknologi Pendidikan. Vol. (5). No. 6, hal. 172-173.

Musliman, R., Rahayah, S., \& Din, R. (2013). Assessing students' spatial intelligence for literacy and numeracy skills. Procedia - Social and Behavioral Sciences, 695-701. https://doi.org/10.1016/j.sbspro.2013.07.142

Kharizmi, Muhammad. (2015). Kesulitan siswa sekolah dasar dalam meningkatkan kemampuan literasi. JUPENDAS, ISSN 2355-3650, Vol. 2, No. 2, September 2015

Ramandanu, Febriana. (2019). Gerakan literasi sekolah (GLS) melalui pemanfaatan sudut baca kelas sebagai sarana alternatif penumbuhan minat baca siswa. Jurnal Mimbar Ilmu, Vol. 24 No. 1, 2019

Pradana, Fransiska Ayuka Putri. (2020). Pengaruh budya literasi sekolah melalui pemanfaatan sudut baca terhadap minat membaca siswa di sekolah dasar. JURNAL Pendidikan dan Konseling, Volume 2 No 1 Tahun 2020 Halaman 81-85

Gilang,L., Sihombing, R.M., dan Sari, N. (2017). Kesesuaian konteks dan ilustrasi pada buku bergambar untuk mendidik karakter anak usia dini. Jurnal Pendidikan Karakter, Tahun VII, Nomor 2, Oktober 2017

Programme for international student assessment (PISA) Results from PISA 2015". Retrieved from OECD 2015. Protection Agency website: www.oecd.org.edu/pisa

Purpura, D. J., Hume, L. E., Sims, D. M., \& Lonigan, C. J. (2011). Journal of Experimental Child Early literacy and early numeracy : The value of including early literacy skills in the prediction of numeracy development. Journal of Experimental Child Psychology, 110(4), 647-658. https://doi.org/10.1016/j.jecp.2011.07.004 
Rakhmawati, Y., \& Mustadi, A. (2019). Self-efficacy in Primary Schools Students as Potential Characters: From the Perspective of Students' Self-ability and Interest. Mimbar Sekolah Dasar, 6(1), 55-67. doi:http://dx.doi.org/10.17509/mimbar-sd.v6i1.15221.

Reed, P. A. (2001). Learning style and laboratory preference: A study of middle school technology education teachers in Virginia. Journal of technology education, Vol. 13, No 1: 59-70

Schunk, D. H. (2012). Learning Theories, and Educational Perspective (6th ed.). Boston, MA Pearson Education Inc.

Sejpal, DR. Kandarp. (2013). Modular Method of teaching Principal. International Journal for Research in Education Vol. 2, Issue:2, February 2013 (IJRE) ISSN:2320-091X

Smith, J. (2013). Reflective practice. Dalam Anne D. Cockburn \& Graham Haandscomb (Eds). Teaching children 3-11: a student's guide ( $3^{\text {rd }}$ ed). London: SAGE Publications Ltd

Stecey, K \& Tuner, R. (2015). Assessing mathematical literacy. The PISA experience, Australia: Springer, 2015

Suharna, H. a. (2013). Berpikir reflektif mahasiswa dalam menyelesaiakan masalah matematika. KNPM V Himpunan Matematika Indonesia, 280-290.

Sugiyono. (2017). Metode Penelitian Kuantitatif, Kualitatif, dan R\&D. Bandung: Alfabeta.

Tariah, D.C Inko. (2014). Assessment of Literacy and Numeracy Levels of Junior Secondary School Students in the Rivers State of Nigeria. Journal of Education and Practice, ISSN 2222-1735 (Paper) ISSN 2222-288X (Online), Vol.5, No.19, 2014

Winkel. (2009). Psikologi pengajaran. Yogyakarta: Media Abadi. 